\title{
Processamento linguístico e processamento auditivo temporal em crianças com distúrbio específico de linguagem $* * * * * * *$
}

\author{
Linguistic and auditory temporal processing in children with specific \\ language impairment
}

\author{
Talita Fortunato-Tavares* \\ Caroline Nunes Rocha** \\ Claudia Regina Furquim de Andrade*** \\ Débora Maria Befi-Lopes**** \\ Eliane Schochat**** \\ Arild Hestvik***** \\ Richard G. Schwartz******
}

*Fonoaudióga. Doutoranda em Ciências pela Faculdade de Medicina da Universidade de São Paulo (USP). Endereço para correspondência: Rua Cipotânea, 51 - São Paulo - SP - CEP 05360-160

(tfortunato-tavares@usp.br).

**Fonoaudióloga. Mestranda em Ciências pela Faculdade de Medicina da USP.

****Fonoaudióloga. Professora Titular do Departamento de Fisioterapia, Fonoaudiologia e Terapia Ocupacional da Faculdade de Medicina da USP.

****Fonoaudióloga. Livre Docente. Professora Associada do Departamento de Fisioterapia, Fonoaudiologia e Terapia Ocupacional da Faculdade de Medicina da USP

******Linguista. Professor Associado do Departmento de Linguística e Ciências Cognitivas da University of Delaware.

******Fonoaudiólogo. Professor Titular do Ph.D. Program in Speech and Hearing Sciences Program - Graduate Center of the City University of New York.

*******Trabalho Realizado no Serviço de Fonoaudiologia do Instituo Central do Hospital das Clínicas da Faculdade de Medicina da USP.

Artigo Original de Pesquisa

Artigo Submetido a Avaliação por Pares

Conflito de Interesse: não

Recebido em 17.08.2009.

Revisado em 02.10.2009.

Aceito para Publicação em 02.10.2009.

\begin{abstract}
Background: several studies suggest the association of specific language impairment (SLI) to deficits in auditory processing.It has been evidenced that children with SLI present deficit in brief stimuli discrimination. Such deficit would lead to difficulties in developing phonological abilities necessary to map phonemes and to effectively and automatically code and decode words and sentences. However, the correlation between temporal processing (TP) and specific deficits in language disorders - such as syntactic comprehension abilities - has received little or no attention. Aim: to analyze the correlation between: TP (through the Frequency Pattern Test - FPT) and Syntactic Complexity Comprehension (through a Sentence Comprehension Task). Method: Sixteen children with typical language development $(8 ; 9 \pm 1 ; 1$ years $)$ and seven children with SLI $(8 ; 1 \pm 1 ; 2$ years) participated on the study. Results: Accuracy of both groups decreased with the increase on syntactic complexity (both $\mathrm{p}<0.01$ ). On the between groups comparison, performance difference on the Test of Syntactic Complexity Comprehension (TSCC) was statistically significant $(\mathrm{p}=0.02)$. As expected, children with SLI presented FPT performance outside reference values. On the SLI group, correlations between TSCC and FPT were positive and higher for high syntactic complexity $(r=0.97)$ than for low syntactic complexity $(r=0.51)$.Conclusion: Results suggest that FPT is positively correlated to syntactic complexity comprehension abilities. The low performance on FPT could serve as an additional indicator of deficits in complex linguistic processing. Future studies should consider, besides the increase of the sample, longitudinal studies that investigate the effect of frequency pattern auditory training on performance in high syntactic complexity comprehension tasks.
\end{abstract}

Key Words: Child Language; Child Development; Hearing.

\section{Resumo}

Tema: diversos estudos sugerem a associação do distúrbio específico de linguagem (DEL) ao déficit no processamento auditivo. Pesquisas fornecem evidência de que a discriminação de estímulos breves estaria comprometida em crianças com DEL. Este déficit levaria a dificuldades em desenvolver habilidades fonológicas necessárias para mapear fonemas e decodificar e codificar palavras e frases efetiva e automaticamente. Entretanto, a correlação entre processamento temporal (PT)e distúrbios de linguagem tem recebido pouca atenção.Objetivo: analisar a correlação entre duas as áreas: PT (teste de padrão de frequiência - TPF) e Processamento Lingüístico (complexidade sintática). Método: Dezesseis crianças com desenvolvimento típico de linguagem $(8 ; 9 \pm 1 ; 1)$ e sete crianças diagnosticadas com DEL $(8 ; 1 \pm 1 ; 2)$ e participaram de TPF e Testes de Compreensão de Complexidade Sintática (TCCS).Resultados: A porcentagem de acerto no TCCS decresceu com o aumento da complexidade sintática $(\mathrm{p}<0,01)$. Na comparação inter-grupos, a diferença no desempenho no TCCS foi estatisticamente significante $(\mathrm{p}=0,02)$. Como esperado, crianças com DEL apresentaram desempenho no TPF fora dos valores de referência.No grupo DEL, as correlações entre os resultados do TPF e do TCCS foram positivas e maiores para frases de alta complexidade sintática $(\mathrm{r}=0,97)$ do que para frases com baixa complexidade sintática $(r=0,51)$. Conclusão: Resultados sugerem que o TPF está correlacionado positivamente com habilidades de complexidade sintática. $\mathrm{O}$ baixo desempenho no TPF pode servir de um indicativo adicional sobre déficits em processamento lingüístico complexo.Estudos futuros devem considerar, além do aumento da amostra,a análise do efeito do treinamento auditivo temporal de freqüência no desempenho em tarefas de compreensão sintática de alta complexidade.

Palavras-Chave: linguagem infantil; desenvolvimento infantil; audição.

Referenciar este material como:

Fortunato-Tavares T, Rocha CN, Andrade CRF de, Befi-Lopes DM, Schochat E, Hestvik A, Schwartz RG. Linguistic and auditory temporal processing in children 3 with specific language impairment (original title: Processamento linguístico e processamento auditivo temporal em crianças com distúrbio específico de linguagem). Pró-Fono Revista de Atualização Científica. 2009 out-dez;21(4):279-84. 


\section{Introduction}

Specific Language Impairment (SLI) affects approximately $7 \%$ of the population - generally more boys than girls are affected 1 . The diagnosis of SLI is commonly made through exclusion criteria, i. e. these children present a language disorder in absence of hearing loss, alterations on cognitive development and speech motor development, syndrome, neurosensorial alterations and acquired neurological lesions $2,3,4,5$. They present, already in the beginning of development, a delayed or disordered syntax development, which can be observed as early as the onset of syntax production and comprehension. There is also evidence that children with SLI present persistent difficulties in comprehension and production of syntactically complex sentences 6 .

Several authors try to explain the nature of language development alterations. Among them, Bishop2 discusses a few hypotheses. The first hypothesis considers that the linguistic competence of the child is intact but the child presents difficulties in transforming the linguistic information in speech signal. The second hypothesis considers this impairment as a consequence of alteration on auditory perception. The third one proposes that language alterations would occur due to deficits in innate neurologic mechanisms specialized in linguistic processing. The fourth one discusses the hypothesis of the language development alterations being a consequence of the limitation on the capacity of verbal memory information processing.

In a later study, MacArhur and Bishop7 discussed the relation of SLI with factors such as limited processing and working memory capacity and to a deficient ability for the acquisition of grammatical rules. The authors also added a poor auditory processing as an SLI risk factor once it could affect the ability to discriminate speech sounds. According to the authors, a deficit in auditory processing could result in less stable neural representations of speech sounds which, in last instance, would interfere on the speech perception and production. Moreover, the authors reported altered temporal auditory processing only in children with SLI who also presented deficits in the ability of frequency discrimination, showing evidence that frequency discrimination was the area of the temporal auditory processing of a more significant deficit in children with SLI.

Agreeing to discussions of MacArhur and Bishop7, several other studies on language development disorders suggest an abnormal neural decodification of auditory information. At approximately 30 years ago, Tallal and Piercy8 identified, in a group of children with SLI, difficulties in identifying tones that were brief or fast, besides the fact that all children presented normal hearing. Such results led the authors to conclude that language development alterations were caused by deficits in processing auditory stimuli presented rapidly 9,10. This has then been called the Temporal Processing (TP) theory.

Subsequently, several studies also suggest an association of SLI to the processing of fast auditory sequence processing 11,12. According to the authors, this deficit affects the development of the ability to detect and process the acoustic and dynamic speech patterns. This would bring difficulties in developing phonological abilities necessary to map phonemes and to code and decode words and sentences effectively and automatically, explaining, then, language difficulties presented by these children.

In sum, the TP theory from Tallal has stimulated a great body of research. However, several questions still remain unanswered. We know that the SLI population is diverse 13 and maybe this would be the reason for such diverse results obtained on TP studies not contributing to deeper clarification. Furthermore, it is known that the SLI population also presents a great diversity in linguistic abilities specifically 13. Maybe a possible correlation between linguistic abilities and auditory temporal processing would indicate that deficits in specific characteristics of the referred processing would implicate deficits in linguistic abilities related to it.

The study of the correlation between auditory perception and representation of speech and linguistic processing in children with SLI could provide valuable information such for a differential diagnoses as for a more effective Speech Language Pathology intervention. However, the correlation between TP and language disorders has received little or no attention in literature - associations between deficits in auditory tasks and language disorders are not clear and need to be explained. Particularly, it is not clear whether performance in tests that assess the temporal auditory processing would reflect perceptual deficits and whether such deficits would be related to language disorders.

Therefore, the aim of the present study is to analyze the correlation between the abilities: temporal ordering and inter-hemispheric transference of the temporal auditory Processing (pitch pattern sequence test) and language (syntactic 
comprehension). Our hypothesis is that children who present poor performance in tasks of syntactic comprehension will also present low performance in the pitch pattern sequence test. This hypothesis is based on the assumption that given that syntactic processing is directly dependent in ordering relations among syntactic elements it would, therefore, be highly correlated to auditory temporal processing. Furthermore, we hypothesize that this correlation will increase according to syntactic complexity.

\section{Methods}

This study was approved by the Research and Ethics Committee of the institution (CAPPesq HCFMUSP) under process 1049/07. Parents of all participants signed a consent form agreeing with the procedures and posterior publication of results according to Resolution 196/96 (BRASIL. Resolution MS/CNS/CNEP n ${ }^{\circ}$ 196/96 from October 10, 1996).

\section{Participants}

Twenty-three children divided into two groups (SLI and Typical Language Development - TLD) participated in the study.

The TLD group was composed by 16 children with typical language development who were between eight and ten years of age $(8 ; 9 \pm 1 ; 1)$. The SLI group was composed by seven children (four boys and three girls - following epidemiological data that SLI affects more boys than girls14) between eight and tem years of age $(8 ; 11 \pm 1 ; 2)$. All participants of the SLI group presented the inclusion criteria for SLI 15. Additional criteria for inclusion on the SLI group were: to present performance on the ABFW: Teste de Linguagem Infantil16 outside reference values in vocabulary and phonology abilities and to be, at the moment of data collection, receiving Speech and Language Therapy.

For a better organization of this session, we will separately present specific methods for each test (Pitch pattern sequence test and Syntax Comprehension).

Pitch pattern sequence test

Equipments

Materials used on the Pitch pattern sequence test were: Otoscope from Heine; middle ear analyzer from Grason - Stadler model GSI - 33; audiometer from Grason - Standler model GSI-61 - with two independent channels calibrated according to ANSI - 1989 standards and equipped with Telephonics phones model TDH - 50P; and portable CD player attached to the audiometer GSI-61.

\section{Procedures}

Participants were submitted to inspection of external acoustic meatus, threshold audiometry, play audiometry, tympanometry, and research of ipsi and contra lateral acoustic reflexes for threshold confirmation. Following, the pitch pattern sequence test18 (PPST) that assesses the ability of temporal ordering and interhemispheric transference was carried out.

The behavioral test - assessment of the temporal auditory processing - was analyzed according to the percentage of correct responses and to the comparison of results with the normalized values for the Brazilian population 19.

\section{Syntax Comprehension Test}

\section{Equipments}

The task of syntax comprehension was designed and presented through the E-Prime Experimental Control Software (PST, Inc.) and run on a laptop computer. Auditory stimuli were presented through loud speakers of the computer with the volume at the same intensity for all participants.

Procedures

A total of 60 sentences were presented according to the following division: 30 sentences with low syntactic complexity (predicate/noun phrase relationship) and 30 sentences with high syntactic complexity (reflexive sentence/ noun phrase relationship). Examples of the two structures are bellow:

Low syntactic complexity (LSC):

Structure: the $\mathrm{X}$ in/in front of/under/behind/ below $\mathrm{Z}$ is $\mathrm{Y}$. Where $\mathrm{X}$ and $\mathrm{Z}$ are substantives and $\mathrm{Y}$ is na adjective (color). Example: $\mathrm{O}$ carro na frente da grade é vermelho (The car behind the fence is red).

High syntactic complexity (HSC): 
Structure:

The A in/in front of/under/behind/below B is C.

Where $A$ and $B$ are substantive and $C$ is a reflexive verbal phrase (with the reflexive pronoun se). Example: O professor na frente do aluno está se olhando (The teacher in front of the student is looking at himself).

For each target sentence, the participant heard a context sentence and then four pictures appeared on the computer screen. The position of the figures on the screen was randomly assigned by the E Prime software. The target sentence was then presented. The participant selected one of the four figures. The next context sentence was presented and then successively until completion of the experiment.

\section{Results}

Results of the language comprehension test (LCT) are shown in Table 1 for both groups (SLI and TLD). We observe that, for both groups, the percentage of correct responses decreased as the syntactic complexity increased.

One Way ANOVAs revealed statistically significant differences between groups (SLI and TLD) on the tasks of low and high syntactic complexity ( $\mathrm{p}>0,05)$.

In our study, children with SLI presented a poorer performance on the PPST when compared to reference values. A substantial variation of performance of the participants was also observed on that test. The PPST was not carried out with the TLD group because reference values for the population with no auditory processing disorder are already published according to age group 19 .

Pearson's Correlations were calculated between results of the PPST and the LCT (for both low and high syntactic complexity) for the SLI group.

The correlation coefficient ( $r$ ) between PPST and LCT - LSC was 0.51 (Figure 1). In contrast, the correlation coefficient ( $r$ ) observed on the comparison between PPST and TCL - HSC was 0,97 (Figure 2), thus indicating an almost perfect positive correlation (Pearson correlation coefficient of value 1 indicates perfect positive correlation).

\section{Discussion}

Performance on the Pitch Pattern Sequence Test

As in several other studies8,9,10,20, children of the present study did present a lower performance on the PPST when compared reference values. The
TABLE 1. Mean percentage accuracy and standard deviation of both groups on the language comprehension test according to syntactic complexity (low or high).

\begin{tabular}{|c|c|c|c|}
\hline Mean Percer & Accur & Standard Devia & \\
\hline \multirow{4}{*}{$\begin{array}{l}\text { Lang uage Comprehension } \\
\text { Test }\end{array}$} & \multirow{2}{*}{ SLI } & $\begin{array}{c}\text { Low Syntactic } \\
\text { Complex ity }\end{array}$ & $60,5(28,2)$ \\
\hline & & $\begin{array}{l}\text { High Syntactic } \\
\text { Complex ity }\end{array}$ & $47,8(21,5)$ \\
\hline & \multirow{2}{*}{ TLD } & $\begin{array}{c}\text { Low Syntactic } \\
\text { Complex ity }\end{array}$ & $93,1(18,5)$ \\
\hline & & $\begin{array}{c}\text { High Syntactic } \\
\text { Complex ity }\end{array}$ & $79,3(19,3)$ \\
\hline
\end{tabular}

FIGURE 1. Correlation between Pitch Pattern Sequence Test (PPST) and the Language Comprehension Test with low syntactic complexity (TCL - LSC) in percentage for the SLI group.

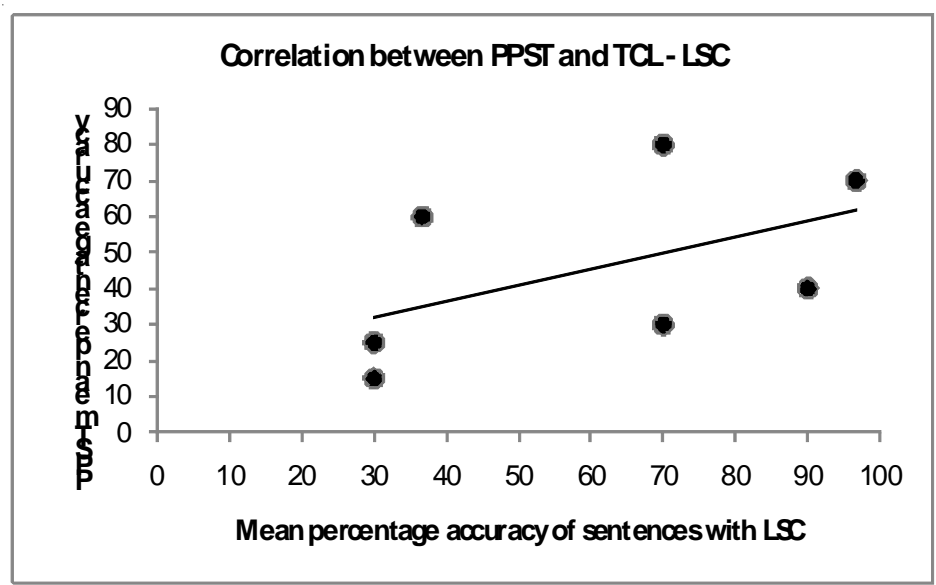

FIGURE 2. Correlation between Pitch Pattern Sequence Test (PPST) and the Language Comprehension Test with high syntactic complexity (TCL - HSC) in percentage for the SLI group.

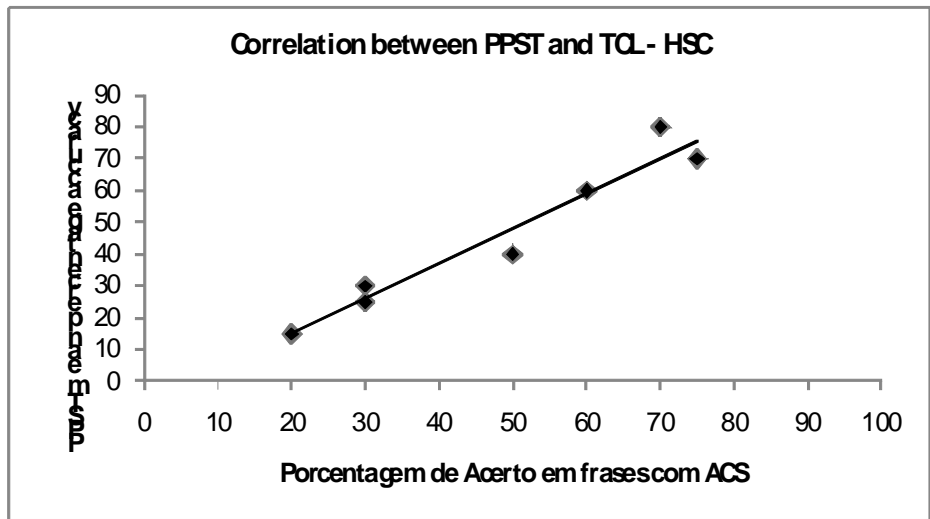


low performance on the PPST observed in children with SLI is related to the difficulty in processing brief auditory sequences of several stimuli. One hypothesis is that such difficult is related to the auditory cortex maturation. Moore and Guan21 found that neurofilaments of axons of the auditory cortex of children with SLI seem not to present complete maturation before 11-12 years of age - therefore, above the age range of participants of this study. In support to those findings, Ponton et al22, Shafer et al 23 and Shafer et al 24 observed a maturational delay in some Event Related Potential components. Furthermore these authors affirm that children with SLI have a limited attention capacity, which could be consequence of such maturational delay. Such findings raise the question of the maturational delay being the cause of problems in temporal auditory processing observed in children with SLI.

Performance on the Language Comprehension Test

As expected, we observed that the syntactic complexity influenced the accuracy rate of participants (Table 1). Children of both groups presented poorer performance on the HSC task when compared to the LSC comprehension task ( $\mathrm{p}<0.05)$. The lower accuracy observed on sentences of HSC might be related to a greater demand of linguistic processing when compared to sentences of LSC.

The difference in linguistic complexity (intrinsic to linguistic processing) was represented in the present study by the contrast between the adjective used in sentences with LSC - and the reflexive pronoun se- used in sentences with HSC. The reflexive pronoun is a closed class word whereas the adjective is an open class word. Closed class words have a syntactic role on linguistic comprehension because they are relatively devoided of meaning. They co-determine syntactic relations among open class words. In other words, closed class words (in the present study represented by the reflexive pronoun se) support the syntactic analysis of a sentence 25 . Therefore, it is possible to affirm that sentences of HSC demand a greater linguistic processing in comparison to sentences of LSC, fact that justifies the present result.

\section{Correlation between PPST and TLC}

Higher correlation was observed between results of PPST and LCT-HSC $(r=0,97)$ when compared to the LCT-LSC $(r=0,51)$. That is, the greater the deficit on the temporal auditory processing is, the worst the performance of these children on tasks of high syntactic complexity is observed. This fact leads us to the comprehension that performance on the PPST and more complex linguistic stimuli are correlated.

The high correlation observed between the two variables can be explained through the hypothesis that the limited ability of children with SLI in processing acoustic characteristics would implicate on other language processing.

Another hypothesis is related to limited processing and verbal working memory7. Several studies defend the theory that children with SLI present general limitations in different types of processing26. Such limitations would be related to cognitive processing (such as working memory) and linguistic processing (such as linguistic complexity) and would affect the development of the ability of detecting and processing the acoustic and dynamic patterns of speech 8,11.

The lower correlation between LCT-LSC with PPST allowed us to exclude the PPST effects over items with lower demand of linguistic processing improving the internal validity of the study. In other words, in case we had only analyzed the correlation between PPST and LCT-HSC we would not be able to conclude that this correlation would be related to linguistic processing - we would not have sufficient data to affirm the contrary: the non correlation with lower syntactic complexity.

The present study references to the analysis that SLI theories - such the ones that defend the auditory processing deficit 9,10 as the main cause of language development alterations; such the ones that defend linguistic and cognitive processing as the main cause - would be related and would not be mutually exclusive.

Therefore, we suggest that a valid theory for the deficits presented in SLI should comprehend both areas once we could observe in the present study that limitations in both systems - linguistic and auditory processing - were shown to be correlated.

\section{Conclusion}

The results allow us to conclude that the PPST test that assesses the auditory processing ability of greater relevance in SLI 8 - is positively correlated with syntactic complexity, that is, with linguistic processing.

The present study also presents valid diagnostic and therapeutic implications. The low performance on the PPST could serve as an additional indicator of deficits in complex linguistic processing. Besides the increase of the sample size, longitudinal studies that analyze the effect of frequency pattern temporal auditory training on the performance on tasks of high syntactic complexity comprehension tasks are suggested. 


\section{References}

1. Tomblin JB. Genetics of child language disorders. In Schwartz RG, Handbook of child language disorders. New York: Psychology Press; 2009.

2. Bishop DVM. The underlying nature of specific language impairment. Journal of Child Psychology and Psychiatry. 1992;33(1):3-66.

3. Rice ML. Specific language impairments: in search of diagnostic markers and genetic contributions. Ment Retard Dev Disabil Res. 1997;3:350-7.

4. Bortollini U, Leonard L. Phonology and children with SLI - Status of structural constraints in two languages. Journal of Communication Disorders. 2000;33(2):131-50.

5. Befi-Lopes DM. Avaliação, diagnóstico e aspectos terapêuticos nos distúrbios específicos de linguagem. In: Ferreira LP; Befi-Lopes DM; Limongi SCO (org.). Tratado de Fonoaudiologia. Roca; 2004. p. 547-52.

6. Fletcher P. Syntax in child language disorders. In R. G. Schwartz (Ed.) Handbook of child language disorders. New York: Psychology Press; 2009.

7. McArthur GM, Bishop DVM. Which people with specific language impairment have auditory processing deficits? Cognition and Neuropsycholy. 2004;21:79.

8. Tallal P, Piercy M. Defects of non-verbal auditory perception in children with developmental dysphasia. Nature. 1973;241:468-9.

9. Tallal P. Auditory temporal perception, phonics, and reading disabilities in children. Brain and Language. 1980; 9:182-98.

10. Miller S, Delaney T, Tallal P. Speech and other central auditory Processes: Insights from Cognitive Neuroscience. Current Opinions in Neurobiology. 1995;5:198-204.

11. Rosen S (1999). Language Disorders: A problem with auditory processing? Current Biology; 9:18.

12. Cohem-Mimmram R (2006). Temporal processing deficits in hebrew speaking children with reading disabilities. Journal of Speech Language and Hearing Research; 49:12737.

13. Schwartz RG (2009). Specific language impairment. In Handbook of Child Language Disorders, R. G. Schwartz (Ed.). New York: Psychology Press.

14. Tomblin JB, Records NL, Buckwalter P, Zhang X, Smith E, O'Brien M (1997). Prevalence of specific language impairment in kindergarten children. Journal of Speech and Hearing Research; 40(6):1245-60.
15. Stark R and Tallal P (1981). Selection of children with specific language disabilities. Journal of Speech and Hearing Disorders; 46:114-22.

16. Andrade CRF, Befi-Lopes DM, Fernandes FD, Wetzner HF (2004). ABFW: teste de linguagem infantil. São Paulo: Pró-Fono.

17. Befi-Lopes DM, Bento ACP, Perissinoto J (2008). Narração de histórias por crianças com distúrbio específico de linguagem [Narrative of children with specific language impairment]. Pró-Fono; 20:93-8.

18. Auditec 1997. Evaluation manual of pitch pattern sequence and duration pattern sequence. Missouri, USA: Auditec; 1997.

19. Balen (2001). Reconhecimento de padrões auditivos de frequência e de duração em crianças escolares de 7 a 11 anos. [tese] São Paulo: Instituto de Psicologia da Universidade de São Paulo; 2001.

20. Hill PR, Hogben JH, Bishop DVM. Auditory frequency discrimination in children with Specific Language Impairment: a longitudinal study. Journal of Speech Language and Hearing Research; 48.

21. Moore e Guan 2001, Moore JK \& Guan YL. Cytoarchitectural and axonal maturation in human auditory cortex. Journal of the Association for Research in Otolaryngology. 2001;2:297-311.

22. Ponton CW, Eggermont JJ, Kwong B, Don M. Maturation of human central auditory system activity: Evidence from multi-channel evoked potentials. Clin Neurophysiol. 2000;111:220-36.

23. Shafer VL, Schwartz RG, Morr ML, Kessler KL, Kurtzberg D. Deviant neurophysiological asymmetry in children with language impairment. Neuroreport. 2000;11:3715-18.

24. Shafer VL, Ponton C, Datta H, Morr ML, Schwartz RG. Neurophysiological indices of attention to speech in children with specific language impairment. Clin Neurophysiol. 2007 Jun 118(6):1230-43.

25. Keurs M, Brown C, Hagoort P \& Stegeman D (1999). Electrophysiological manifestations of open- and closedclass words in patients with Broca's aphasia with agrammatic comprehension: An event-related brain potential study. Brain; 122:839-54.

26. Gillam RB, Montgomery JW, Gillam SL (2009). Attention and Memory in Child Language Disosrders. In Schwartz RG, Handbook of Child Language Disorders. New York, Psychology Press. 